\title{
EVALUATION OF THE AVAILABILITY OF MASS OF FORAGE: MORPHOLOGICAL RESPONSES AND CHEMICAL COMPOSITION OF TANZANIA GRASS SUBJECTED TO TWO PASTURE-MANAGEMENT STRATEGIES
}

\author{
AVALIAÇÃO DA DISPONIBILIDADE DA MASSA DA FORRAGEIRA: RESPOSTAS \\ MORFOLÓGICAS E COMPOSIÇÃO QUÍMICA DO TANZÂNIA SUJEITO A DUAS \\ ESTRATÉGIAS DE MANEJO DE PASTAGEM
}

\section{Michele Gabriel CAMILO'; Alberto Magno FERNANDES²; Tadeu Silva De OLIVEIRA²; Danielle Ferreira BAFFA'; Sarah Ellen Eduardo BERNARDO ${ }^{3}$; Camila Da Conceição CORDEIRO'}

1. Universidade Estadual do Norte Fluminense Darcy Ribeiro, Programa de Pós-graduação em Ciência Animal, Campos dos Goytacazes, RJ, Brasil; 2. Universidade Estadual do Norte Fluminense Darcy Ribeiro, Programa de Pós-graduação em Ciência Animal,Campos dos Goytacazes, RJ, Brasil. tadeuzootecnista@gmail.com; 3. Universidade Estadual do Norte Fluminense Darcy Ribeiro, Programa de Pós-graduação em Ciência Animal, Campos dos Goytacazes, RJ, Brasil

\begin{abstract}
The objective of this study was to evaluate the morphogenetic traits and chemical composition of Tanzania grass using a fixed rest period or according to light interception at $95 \%$. The treatments consisted of evaluations of two Tanzania-grass pasture-management strategies: (1) LI95 - animals entered the paddocks when the pasture reached $95 \%$ of light interception (LI), with three days of paddock occupation; and (2) FR - the pasture was managed with a defoliation interval (DI) of 30 days, and three days of paddock occupation. The experimental area consisted of 4 ha, with 22 paddocks per treatments. Ten recentlycalved cows were used per treatment in year 1, and eight cows were used per treatment in year 2. Sward height, forage mass, and morphological components and their chemical composition were evaluated. The management strategies used on the Tanzania grass pasture did not affect pasture mass or height in the pre- and post-grazing conditions, or the proportion of stems. However, the proportion of leaves was greater in the paddocks with $95 \%$ light interception. The crude protein content was higher in the paddocks with $95 \%$ light interception; the other nutrients were not affected. In conclusion, management adopting 95\% light interception does not influence morphogenetic traits. Nevertheless, it promotes an increase in the crude protein content of grasses.
\end{abstract}

KEYWORDS: Cutting intensity. Light interception. Paddocks. Stocking rate.

\section{INTRODUCTION}

In Brazil, a large proportion of studies on grazing management focusing on plant characteristics and environment conditions are primarily grounded on rest intervals, stocking rates, and/or cutting intensity/fixed grazing, and they seldom respect the plant physiology, with no proper control of the structural characteristics of the forage sward (e.g., leaf area index), which are essential variables for proper defoliation management and use of the produced forage (SANTOS et al., 2013). As a consequence, pasture performance is rather variable and inconsistent, resulting in a high level of dissatisfaction on the part of producers and technicians of this sector.

The successful use of forage depends on understanding the morphophysiological mechanisms and their interaction with the environment. The accumulated of forage at the start of regrowth consists basically of leaves (WANG; BUGHRARA; NELSON, 2008). As the plant grows, intraspecific competition for light increases progressively; stem elongation, leaf senescence and tiller mortality elevate; whereas leaf accumulation decreases. These morphophysiological changes occur after interception of $95 \%$ of the incoming light by the sward, which has characterized this moment as ideal for an interruption of regrowth (ZANINE et al., 2016), since all the energy used by grass throughout the growing season is obtained from solar radiation (RAY; SINCLAIR, 1998).

Therefore, identifying the condition that maximizes the efficiency of pasture production requires information of the growth and development dynamics of plants which make up a pasture, by means of morphogenesis is relevant, for it allows the understanding of how the plant works and helps at the establishment of practices more suitable for the grazing management (ZANINE et al., 2016). 
Given the foregoing, the objective of this study was to evaluate the morphogenetic traits and chemical composition of Tanzania grass using a fixed rest period and with 95\% light interception.

\section{MATERIALS AND METHODS}

\section{Local characteristics, experimental design and treatments}

The experiment was conducted at Embrapa

Dairy Cattle, on the José Henrique Brushi

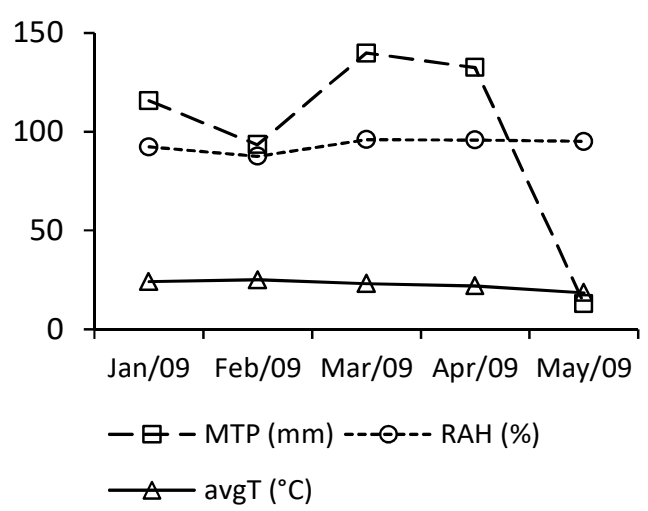

CAMILO et al.

experimental field, located in the municipality of Coronel Pacheco/MG, Brazil (2132'38" South latitude, $43^{\circ} 15^{\prime} 10^{\prime \prime}$ west longitude, $451 \mathrm{~m}$ altitude). According to the Köppen classification, the climate of the region is the Cwa (tropical altitude) type, with rainy and hot summers and dry winters between June and September. The experiment took place between January and May of 2009 (year 1) and 2011 (year 2). Meteorological data referring to the experimental period can be seen in Figures $1 \mathrm{a}$ and $b$.

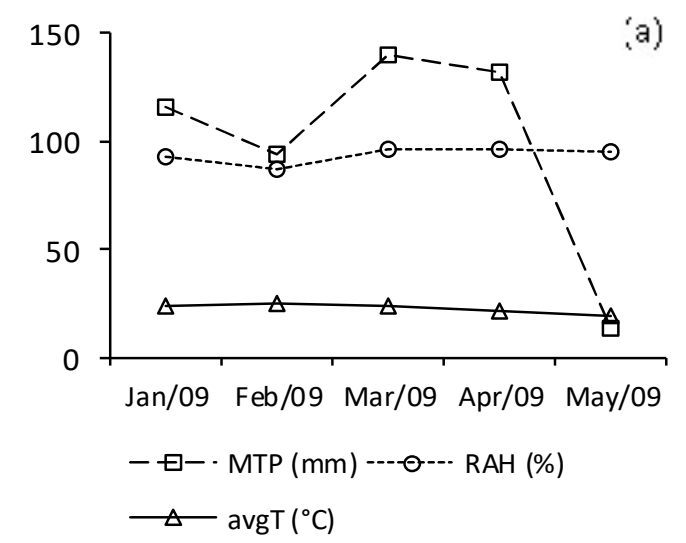

Figure 1. Monthly total precipitation (MTP), relative air humidity (RAH) and average monthly temperature (avgT) during the experimental period in year 1. Note: The months of February, March, April and May represent cycles 1, 2, 3 and 4, respectively (a) and during the experimental period in year 2 . Note: The months of February and March represent cycles 1 and 2, respectively (b).

Daily-precipitation was graphed (Figure 2) to emphasize an anomalous period without rainfall, which occurred in the first months of year 2 (January and February).

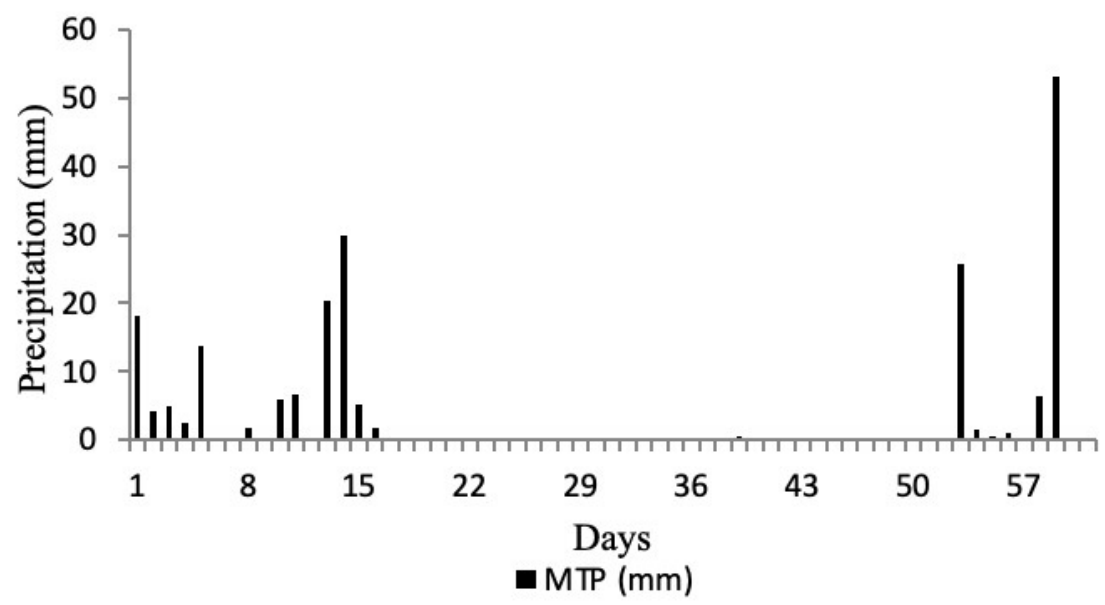

Figure 2. Daily total precipitation (DTP) in the period from January to February in year 2.

The experimental area consisted of 4 ha, divided into 44 paddocks with approximately 909 $\mathrm{m}^{2}$ each. Each treatment was allocated to two field experimental units, and each unit was formed by an area of 11 paddocks. Treatments consisted of evaluations of two Tanzania-grass pasturemanagement strategies: (1) LI95 - animals entered the paddocks when the pasture reached $95 \%$ light interception (LI), with 3 days of paddock occupation; and (2) FR - the pasture was managed 
with a 30-day defoliation interval (DI) and 3 days of paddock occupation. In the LI95 treatment, three additional $909 \mathrm{~m}^{2}$ paddocks were prepared with the aim of adjusting the LI in the different grazing cycles, insofar as the DI could be shorter or longer than the adopted interval of 30 days, depending on the LI. However, due to climatic conditions, the observed DI in LI95 was always below or the same as the adopted interval of 30 days. Prior to the beginning of data collection, the pastures in the two treatments were managed to establish the postgrazing residual heights at $30 \mathrm{~cm}$. This management consisted of mechanical thinning performed with a backpack mower, to form a plant-age gradient in each paddock.

\section{Monitoring of light interception, fertilizing and grazing}

The interception of light by the sward was monitored pre-grazing at every seven days, and when the LI was close to the target of $95 \%$ the monitoring frequency was two days. A variation of $\pm 2 \%$ in LI was considered as criterion for entry of animals into the paddocks due to the little variation observed in the forage mass. An AccuPAR Linear PAR/LAI ceptometer Model PAR-80 (Decagon Devices) sward analyzer was used for the evaluations of LI, with which readings were made at ten points per paddock. Three readings were taken in each point above the forage sward and another three at the soil level in representative points (taking topsoil into account) of the paddock in each replicate and in each grazing cycle.

The paddocks were fertilized with $\mathrm{N}$ and $\mathrm{K}_{2} \mathrm{O}$ at $220 \mathrm{kgha}^{-1} \mathrm{yr}^{-1}$, and $\mathrm{P}_{2} \mathrm{O}_{5}$ at 55 $\mathrm{kgha}^{-1} \mathrm{yr}^{-1}$. The fertilizer was distributed by broadcasting whenever the animals were switched among paddocks over the grazing cycles, such that the nutrients were supplied in all paddocks when the pasture showed the same physiological age. Therefore, the year dose was split into equally portions and applied over the paddocks whenever the animals were switched.

The experimental unit was formed by five crossbred cows grazing on 11 paddocks. Therefore, per treatment in year 1, two experimental units were allotted and 10 crossbred cows (Holstein $\times$ Gir) were used. In year 2 , four crossbred cows grazing 11 paddocks formed the experimental unit, and two experimental units were allotted per treatment. Therefore, eight fresh crossbred cows (Holstein $\times$ Gir) were used. During the experimental period, all cows were supplemented with concentrate at $2 \mathrm{~kg}$ day $^{-1}\left(\mathrm{CP}=236.9 \mathrm{~g} \mathrm{~kg}^{-1}\right)$, and minerals were supplied ad libitum.

\section{Evaluation of morphogenetic and structural characteristics}

Sward height was determined by using a ruler graduated in centimeters, with 20 random points measured per paddock. The height of each point corresponded to the average height of the sward around the ruler. Plant-height readings were taken in the pre-grazing condition, when the paddocks reached the stipulated LI level, and in the post-grazing condition, immediately after the animals exited. The average sward height values were also recorded concurrently with the intermediate LI readings.

The forage mass pre- and post-grazing was estimated by using a $1 \mathrm{~m}^{2}$ metal frame at six representative points of the average sward height in each paddock. The material contained in each square was cut at the soil level.

A representative fraction of the samples harvested to determine the forage mass pre- and post-grazing was collected to evaluate the forage morphological components. This fraction was separated into the leaf-blade, stem (stem + sheath) and dead material (dry leaves and stems) fractions, which were weighed and dried in a forced aircirculation oven at $55{ }^{\circ} \mathrm{C}$ until they reached a constant weight. The forage-mass values were converted to $\mathrm{kg} / \mathrm{ha} \mathrm{DM}$ and the morphological components were expressed as a proportion $\left(\mathrm{g} \mathrm{kg}^{-1}\right)$ of the forage mass.

\section{Evaluation of the chemical composition}

In year 1 , the diet was sampled utilizing the extrusa, and four animals fistulated in the esophagus (two per treatment) were utilized to obtain representative samples of the diet. On the sampling days, the fistulated animals were moved to the barnyard and deprived of feed for $12 \mathrm{~h}$; next, they were transferred to the paddocks to graze for approximately $30 \mathrm{~min}$, and the material was sampled. The samples were conditioned in plastic bags and stored in a freezer at $-15{ }^{\circ} \mathrm{C}$ until the end of the collection period.

Extrusa samples were collected in all grazing cycles; after thawing, they were pre-dried in a forced-ventilation oven at $\pm 55^{\circ} \mathrm{C}$ for $72 \mathrm{~h}$, then processed in a knife mill with $1 \mathrm{~mm}$ sieve and stored in glass bottles at room temperature for laboratory analyses.

In year 2, the hand-plucking method (grazing simulation) was utilized, and samples of 
Evaluation...

the material originating from the pasture regrowth were collected at the height of the forage sward above the residual. Three collections were made per cycle in paddocks chosen at random. These samples were separated into leaves and stems, pre-dried in a forced-ventilation oven at $\pm 55{ }^{\circ} \mathrm{C}$ for $72 \mathrm{~h}$, then processed in a knife mill with $1 \mathrm{~mm}$ sieve, and finally stored in glass bottles at room temperature for laboratory analyses.

All pasture samples that originated from extrusa (year 1) and by hand-plucking (year 2), were analyzed for contents of dry matter (DM, method 967.03 - AOAC, 1990), mineral matter (MM, method 942.05 - AOAC, 1990), ether extract (EE, method 920.29 - AOAC, 1990) and crude protein (CP, method 981.10 - AOAC, 1990), and neutral detergent fiber (VAN SOEST; ROBERTSON, LEWIS, 1991). Non-fiber carbohydrates (NFC) and fiber carbohydrates (fiber) were determined according to Sniffen et al. (1992).

\section{Statistical analysis}

The following mixed model was used to analyses the data pertaining to the chemical composition of the consumed grass, forage mass above ground, sward height, and proportion of senescent and vegetative plant tissues:

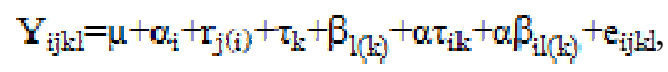

in which $\mathrm{Y}_{\mathrm{i} \mathrm{i} \mathrm{k} \text { l }}$ corresponds to the observation measured on the $\mathrm{j}$-th replicate of area, in which the $\mathrm{i}$-th treatment was applied during the $\mathrm{k}$-th year and 1-th grazing cycle; $\mu$ represents the overall mean; $\alpha_{i}$ corresponds to the effect of the $\mathrm{i}$-th treatment $(\mathrm{i}=1$, $2) ; r_{j}(i)$ represents the effect of the $j-h$ replicate of area within the i-th treatment; $\tau_{\mathrm{k}}$ represents the effect of the $k$-th year $(k=1,2) ; \beta_{1(k)}$ represents the effect of the 1-th grazing cycle within the k-th year; $\alpha \tau_{i k}$ is the interaction between the $\mathrm{i}$-th treatment and the $\mathrm{k}$-th year; $\alpha \beta_{\mathrm{ing}}$ is the interaction between the ith treatment and the 1-th grazing cycle within the kth year; and $e_{i j k}$ corresponds to the random error, assumed normal, independent, and identically distributed, with mean zero and variance $\sigma^{2}$.

The parameters were estimated using the Mixed procedure of SAS software, version 9 (SAS
CAMILO et al.

Institute, Cary, NC, USA), in which the best covariance structure was chosen according to the calculation of the corrected Akaike information criterion (AlCcr; AKAIKE, 1974) and the derived measures likelihood probability and evidence ratio (BURNHAM; ANDERSON, 2004). The tested covariance structures, were: variance components, heterogeneous-variance components, compound symmetry, first-order autoregressive correlations, Toeplitz, and the unstructured (LITTELL et al., 2006).

\section{RESULTS}

\section{Evaluation of morphogenetic and structural characteristics}

For the variables proportion of dead material, pasture height pre-grazing, post-grazing forage mass, and post-grazing pasture height the variance-covariance structures was heterogeneousvariance components. For forage mass pre-grazing was first-order autoregressive.

The treatments employed, and the duration of grazing cycles varied in the LI95 treatment. In year 1 (2009), cycles 1, 2, 3, and 4 lasted 24, 24, 27, and 30 days, respectively. In year 2 (2011), grazing cycles 1 and 2 lasted 27 and 30 days, respectively.

With regard to the proportion of dead material, a treatment effect $(p=0.015)$ was observed, wherein the amount of dead material was $62.3 \pm 13.5 \mathrm{~g} / \mathrm{kg}$ DM with the LI95 treatment and $97.1 \pm 21.0 \mathrm{~g} \mathrm{~kg} \mathrm{DM}^{-1}$ under the FR treatment. The year of study also affected this variable $(p=0.005)$, which had values $56.7 \pm 2.8$ and $106.8 \pm 33.3 \mathrm{~g} \mathrm{~kg}$ $\mathrm{DM}^{-1}$ in years 1 and 2 , respectively. Treatment $\times$ year interaction $(p=0.026)$ and cycle-within-year $(p$ $=0.041)$ also affected this variable (Table 1), whereas the treatment $\times$ cycle-within-year interaction did not affect it $(p=0.118)$. In year 1 , the proportions of dead material with treatments LI95 and FR were $54.8 \pm 3.8$ and $58.6 \pm 4.1 \mathrm{~g} \mathrm{~kg} \mathrm{DM}^{-}$ 1 , respectively, with no statistical difference ( $p=$ $0.381)$. In year 2 , they were $70.8 \pm 31.7$ and $161.1 \pm 72.2 \mathrm{~g} \mathrm{~kg} \mathrm{DM}^{-1}$, respectively, resulting in weak evidence of effect $(0.05<p$-value $<0.10)(p=$ 0.062 ). 
Table 1. Proportion of dead material $\left(\mathrm{g} \mathrm{kg}^{-1} \mathrm{DM}\right)$ and mass $\left(\mathrm{t}^{-1} \mathrm{DM} \mathrm{ha}{ }^{-1}\right)$ of the Tanzania grass pre-grazing for cycle within year.

\begin{tabular}{|c|c|c|c|c|c|c|}
\hline \multirow[b]{2}{*}{ Cycles } & \multicolumn{4}{|c|}{ Year 1} & \multicolumn{2}{|c|}{ Year 2} \\
\hline & 1 & 2 & 3 & 4 & 1 & 2 \\
\hline \multicolumn{7}{|c|}{ Proportion of dead material $\left(\mathrm{g} \mathrm{kg}^{-1} \mathrm{DM}\right)$} \\
\hline Means & $48.2^{\mathrm{b}} \pm 1.1$ & $48.7^{\mathrm{b}} \pm 0.5$ & $63.8^{\mathrm{a}} \pm 13.4$ & $68.9^{\mathrm{a}} \pm 15.6$ & $113.7 \pm 92.7$ & $100.3 \pm 54.4$ \\
\hline \multicolumn{7}{|c|}{ Mean values for mass $\left(t^{-1} \mathrm{DM}^{-1}\right.$ ha $)$} \\
\hline
\end{tabular}

Means followed by the same letter in the same row and in the same year do not differ statistically at $\alpha=0.05$.

Forage mass pre-grazing was not affected by treatment $(p=0.455)$, treatment $\times$ year interaction $(p=0.819)$, or treatment $\times$ cycle-withinyear interaction $(p=0.946)$, but a significant effect was observed between years $(p=0.001)$ and for cycle within year $(p=0.014)$ (Table 1$)$.

Pasture height pre-grazing was not affected by treatment $(p=0.715)$, year $(p=0.091)$, treatment $\times$ year interaction $(p=0.727)$, cycle within year $(p=$ $0.150)$, or the treatment $\times$ cycle-within-year interaction $(p=0.683)$.

The pasture height in the pre-grazing condition, for the LI95 treatment, was $1.1 \pm 0.3 \mathrm{~m}$, and for the FR treatment it was $1.1 \pm 0.3 \mathrm{~m}$.

No effect of treatment $(p=0.199)$, treatment $\times$ year interaction $(p=0.283)$, cycle within year $(p=$ $0.274)$, or treatment $\times$ cycle-within-year interaction $(p=0.959)$ was observed on post-grazing forage mass. A significant effect was only observed between years $(p=0.005)$, in which years 1 and 2 had post-grazing forage masses of $1.9 \pm 0.6$ and $5.6 \pm 1.7 \mathrm{t}^{-1} \mathrm{DM} \mathrm{ha}^{-1}$, respectively. The residual forage mass with the LI95 treatment was $3.3 \pm 1.8 \mathrm{t}^{-1}$ $\mathrm{DM} \mathrm{ha}^{-1}$, and with the FR treatment it was $4.1 \pm 1.6 \mathrm{t}^{-}$
${ }^{1} \mathrm{DM} \mathrm{ha}^{-1}$. Although no statistical difference was observed in the amount of residual mass between the treatments $(p=0.199)$ in either year, there was a marked difference between the years $(p=0.005)$, with a much higher residual mass in year 2 , probably due to the lower stocking rate utilized in that year.

The post-grazing pasture height was not affected by treatment $(p=0.160)$, treatment $\times$ year interaction $(p=0.491)$, cycle within year $(p=$ 0.180 ), or by the treatment $\times$ cycle-within-year interaction $(p=0.717)$, although a significant effect was observed between years $(p=0.008)$, with $0.5 \pm 0.1$ and $0.6 \pm 0.1 \mathrm{~m}$ in years 1 and 2 , respectively.

The proportion of stems was no influenced by treatment $(p=0.457)$ or treatment $\times$ year interaction $(p=0.906)$, but a significant effect was observed between the years $(p=0.004)$, between cycles within the year $(p<0.001)$, and for the treatment $\times$ cycle-within-year interaction $(p=$ 0.001) (Table 2).

Table 2. Proportion of stems and leaves $\left(\mathrm{g} \mathrm{kg}^{-1} \mathrm{DM}\right)$ of the Tanzania grass.

\begin{tabular}{|c|c|c|c|c|c|c|}
\hline & \multicolumn{4}{|c|}{ Year 1} & \multicolumn{2}{|c|}{ Year 2} \\
\hline & \multicolumn{4}{|c|}{ Cycle } & \multicolumn{2}{|c|}{ Cycle } \\
\hline & 1 & 2 & 3 & 4 & 1 & 2 \\
\hline \multicolumn{7}{|c|}{ Proportion of stems $\left(\mathrm{g} \mathrm{kg}^{-1} \mathrm{DM}\right)$} \\
\hline LI95 & $437.4^{\mathrm{b}} \pm 8.3$ & $436.5^{\mathrm{b}} \pm 8.3$ & $586.4^{\mathrm{a}} \pm 11.1$ & $583.2^{\mathrm{a}} \pm 11.0$ & $321.5 \pm 117.1$ & $365.2 \pm 133.1$ \\
\hline FR & $489.0^{\mathrm{b}} \pm 9.3$ & $491.2^{\mathrm{b}} \pm 9.3$ & $587.4^{\mathrm{a}} \pm 11.1$ & $577.6^{\mathrm{a}} \pm 10.9$ & $329.4 \pm 120.0$ & $385.5 \pm 140.5$ \\
\hline$p$-value & $<.001$ & $<.001$ & 1,000 & 0.998 & 1,000 & 1,000 \\
\hline \multicolumn{7}{|c|}{ Proportion of leaves $\left(\mathrm{g} \mathrm{kg}^{-1} \mathrm{DM}\right)$} \\
\hline LI95 & $522.9^{\mathrm{a}} \pm 1.7$ & $517.5^{\mathrm{a}} \pm 15.8$ & $346.1^{b} \pm 15.9$ & $343.5^{b} \pm 16.5$ & $621.6 \pm 165.0$ & $541.7 \pm 247.2$ \\
\hline FR & $456.7^{\mathrm{a}} \pm 1.5$ & $453.5^{\mathrm{a}} \pm 13.9$ & $352.0^{\mathrm{b}} \pm 16.1$ & $357.2^{\mathrm{b}} \pm 17.2$ & $421.7 \pm 111.9$ & $489.4 \pm 223.3$ \\
\hline$p$-value & $<.001$ & 0.006 & 0.967 & 0.518 & 0.144 & 0.999 \\
\hline
\end{tabular}

Means followed by the same letter in the same row and in the same year do not differ statistically at $\alpha=0.05$. 
There was no treatment $\times$ year effect $(p=$ $0.100)$ on the proportion of leaves. However, significant effects of treatment $(p=0.031)$, years $(p$ $=0.011)$, cycle within year $(p=0.001)$, and the treatment $\times$ cycle-within-year interaction were observed on this variable $(p=0.019)$ (Table 2).

\section{Evaluation of chemical composition}

For the variables dry matter, mineral matter, crude protein, non-fiber carbohydrates, and lignin the variance-covariance structures was heterogeneous-variance components. For crude fat, it was variance components.

For forage dry matter, there was no effect of treatment $(p=0.087)$, treatment $\times$ year interaction $(p=0.490)$, cycle within year $(p=0.447)$, or treatment $\times$ cycle-within year interaction $(p=$ 0.928). A significant effect was only observed between years $(p<0.001)$, with $148.9 \pm 11.7$ and $196.1 \pm 14.4 \mathrm{~g} \mathrm{~kg} \mathrm{DM}^{-1}$ in years 1 and 2, respectively.

Regarding the mineral matter (MM) content, there was no effect of treatment $(p=0.267)$, treatment $\times$ year interaction $(p=0.155)$, cycle

\section{CAMILO et al.}

within year $(p=0.641)$ or treatment $\times$ cycle-withinyear interaction $(p=0.578)$. A significant effect was observed only between years $(p=0.002)$, with $110.5 \pm 25.4$ and $116.5 \pm 13.3 \mathrm{~g} \mathrm{~kg} \mathrm{DM}^{-1}$ in years 1 and 2 , respectively.

As regards the crude fat $(\mathrm{CF})$ content, there was no effect of treatment $(p=0.184)$, treatment $\times$ year interaction $(p=0.354)$, cycle within year $(p=$ 0.912 ), or treatment $\times$ cycle-within-year interaction $(p=0.904)$; nevertheless, a significant effect was observed between years $(p<0.001)$, wherein this variable averaged $24.1 \pm 4.1$ and $5.8 \pm 2.8 \mathrm{~g} \mathrm{~kg} \mathrm{DM}^{-1}$ in years 1 and 2, respectively.

The crude protein contents were within the normal range, although they were $(15.86 \%$ to $68 \%$ higher) than the minimum threshold, which, according to Van Soest (1994), is $70 \mathrm{~g} \mathrm{~kg} \mathrm{CP}$ (in the $\mathrm{DM})$ to ensure the fermentation of fibrous carbohydrates in the rumen (Table 3).

Table 3. Crude protein and total carbohydrate contents $\left(\mathrm{g} \mathrm{kg}^{-1} \mathrm{DM}\right)$ of the Tanzania grass.

\begin{tabular}{|c|c|c|c|c|c|c|}
\hline \multicolumn{5}{|c|}{ Year 1} & \multicolumn{2}{|c|}{ Year 2} \\
\hline & \multicolumn{4}{|c|}{ Cycles } & \multicolumn{2}{|c|}{ Cycles } \\
\hline & 1 & 2 & 3 & 4 & 1 & 2 \\
\hline \multicolumn{7}{|c|}{ Crude protein content $\left(\mathrm{g} \mathrm{kg}^{-1} \mathrm{DM}\right)$} \\
\hline LI95 & $117.6^{\mathrm{a}} \pm 2.5$ & $97.5^{\mathrm{c}} \pm 2.3$ & $105.2^{\mathrm{b}} \pm 2.4$ & $100.4^{\mathrm{bc}} \pm 2.4$ & $103.7^{\mathrm{a}} \pm 10.1$ & $81.1^{\mathrm{b}} \pm 9.0$ \\
\hline FR & $111.2^{\mathrm{a}} \pm 2.5$ & $101.1^{\mathrm{b}} \pm 2.4$ & $99.7^{\mathrm{b}} \pm 2.4$ & $89.6^{\mathrm{c}} \pm 2.2$ & $82.9 \pm 9.1$ & $92.6 \pm 9.6$ \\
\hline$p$-value & 0.061 & 0.461 & 0.018 & 0.036 & 0.057 & 0.47 \\
\hline \multicolumn{7}{|c|}{ Total carbohydrate content $\left(\mathrm{g} \mathrm{kg}^{-1} \mathrm{DM}\right)$} \\
\hline LI95 & $726.9^{\mathrm{a}} \pm 37.3$ & $772.6^{\mathrm{a}} \pm 35.1$ & $745.0^{\mathrm{a}} \pm 36.5$ & $754.9^{\mathrm{a}} \pm 36.0$ & $792.9^{\mathrm{b}} \pm 8.9$ & $814.9^{\mathrm{a}} \pm 8.5$ \\
\hline FR & $730.9^{\mathrm{a}} \pm 37.1$ & $746.3^{\mathrm{a}} \pm 36.4$ & $722.0^{\mathrm{a}} \pm 37.5$ & $728.2^{\mathrm{a}} \pm 37.5$ & $816.9 \pm 8.5$ & $803.2 \pm 8.7$ \\
\hline$p$-value & 1.000 & 0.974 & 0.992 & 0.975 & 0.015 & 0.379 \\
\hline
\end{tabular}

Means followed by the same letter in the same row and in the same year do not differ statistically at $\alpha=0.05$.

Non-fiber carbohydrates (NFC) were not affected by treatment $(p=0.265)$, treatment $\times$ year interaction $(p=0.923)$, cycle within year $(p=$ 0.195 ), or treatment $\times$ cycle-within-year interaction $(p=0.238)$. A significant effect was observed only between years $(p<0.001)$, with $147.9 \pm 71.0$ and $237.4 \pm 79.3 \mathrm{~g} \mathrm{~kg} \mathrm{DM}^{-1}$ in years 1 and 2 , respectively.
For lignin, no treatment $(p=0.545)$, treatment $\times$ year interaction $(p=0.295)$, or treatment $\times$ cycle-within-year interaction effects were observed, but significant effects were found between years $(p<0.001)$ and cycle within year $(p$ $=0.005)($ Table 4$)$.

Table 4. Means values of the lignin content $\left(\mathrm{g} \mathrm{kg}^{-1} \mathrm{DM}\right)$ of the Tanzania grass for cycle within year.

\begin{tabular}{ccccccc}
\hline & \multicolumn{3}{c}{ Year 1 } & \multicolumn{3}{c}{ Year 2 } \\
\hline Cycles & 1 & 2 & 3 & 4 & 1 & 2 \\
\hline Means & $58.2 \pm 11.9$ & $66.5 \pm 12.6$ & $65.9 \pm 12.6$ & $77.7 \pm 13.6$ & $35.5^{\mathrm{a}} \pm 2.4$ & $28.7^{\mathrm{b}} \pm 2.2$ \\
\hline
\end{tabular}

Means followed by the same letter in the same row and in the same year do not differ statistically at $\alpha=0.05$. 


\section{DISCUSSION}

\section{Evaluation of morphogenetic and structural characteristics}

The proportion of dead material in year 1 (Table 1) was lower than that of vegetative tissues (stems and leaves). Throughout the grazing cycles, the proportion of dead material was found to increase. The same was observed when the treatments were compared, in which the FR treatment provided the greatest proportions of dead material, as the defoliation interval was longer than that of the LI95 treatment.

Alexandrino, Gomide and Gomide (2005) state that as the sward closes, intercepting almost all incoming light radiation, the senescence process and death of older leaves intensify. This occurred with the FR treatment under high-rainfall conditions, but not in the LI95 treatment, because the animals entered the paddocks on the day the equipment recorded 95\% LI (under such conditions, usually a few days before the occupation of paddocks in the FR treatment), thereby reducing the intensification of the senescence process. This process is controlled by several physiological factors, which are associated with the morphogenesis of the grass and the management strategy employed, a thereby affecting the lifetime of the leaf (LEMAIRE; CHAPMAN, 1996).

However, in year 2, a considerable increase in the proportion of dead material was observed in comparison with that of year 1 , which may partly be explained by precipitation (Figures $1 \mathrm{a}$ and $\mathrm{b}$ ). Shift in the osmotic component of the leaf water potential should influence this overt symptom of water stress. Solute accumulation, particularly the increase in sugars, has also been implicated as a factor increased protoplasmic tolerance for water deficits (LEE-STADELMANN; STADELMANN, 1976), which may be manifest in an altered relationship between tissue death and tissue water relations. Therefore, due to the reduction of the stocking rate, which decreased from five to four cows from the first to the second year.

The reduction in pasture mass, which happened in year 1, cycle 1 (February) in relation to cycle 3 (April) may be a result of the grazing gradient performed in the previous month, because in this month the areas were mowed mechanically so as to define a grazing gradient for the onset of the evaluation period. Thus, this period was the only one in which it was possible to obtain a post-grazing residual height of $30 \mathrm{~cm}$, and hence cycle 1 was the only cycle in which there was residual mass prior to its beginning, which might have contributed to these lower observed values. The lower mass observed in cycle 4 can be explained by the lower rainfall recorded in all cycles of the year (Figure 2).

The height of grasses in year 1 followed the forage mass to some extent (Table 1). Although the defoliation intervals were shorter (variation of 24 to 30 days), it was not sufficient to control the height of the forage sward, which varied from 0.95 to 1.05 $\mathrm{m}$ between the grazing cycles. Probably the amount of remaining leaves, did not affect down the regrowth process. Similar response was observed by Uebele (2002).

The proportion of stems varied within the treatments over the cycles and between treatments, in cycles 1 and 2 of year 1 (Table 2). These proportions may be indicative that, with reduction of the precipitation rates and of the average temperature, and due to flowering in March/April, the plant photosynthesis was reduced, which resulted in a greater elongation of the stems (ALEXANDRINO; GOMIDE; GOMIDE, 2005). The same occurred in year 2, in which lower values of stem were observed, justified by higher precipitation levels in most part of that period, thereby generating greater production of leaves (Table 2) at the expense of stems.

The proportion of stems in year 1 varied within treatments over the experimental period and between treatments, in cycles 1 and 2. This was not true in year 2 neither within nor between treatments. This behavior reflects the results of the previously discussed proportions of dead material and stems, when the reduced rainfall and average temperature, consistent with the time of beginning of flowering, contribute to stem elongation and reduction in the proportion of leaves. The morphogenetic and structural characteristics of plants are strongly influenced by the environmental conditions (LEMAIRE; CHAPMAN, 1996). Higher values were observed in year 2 as compared with those of year 1, probably due to the better precipitation rates associated with the reduction in the stocking rate.

When they graze, cattle tend to consume the forage from the upper layer of the plants, which contains more leaves, i.e., there is a preference for leaves over stem. This selectivity is due to the greater protein and lower fiber contents, which consequently promotes greater digestibility of the leaves than that of stems (VAN SOEST, 1994).

The treatments did not influence the pasture height in the post-grazing conditions, just as observed by Uebele (2002), who also could not keep the residual forage-sward height of Mombasa grass at $30 \mathrm{~cm}$ under grazing with intermittent stocking, adopting a relatively long rest period, which allowed 
for almost complete interception of the light, resulting from the selective grazing practiced by the steers and their low grazing efficiency in a horizon below that defined by the height of the stalks.

A similar phenomenon to the one reported in this study may have also been observed by Uebele (2002), insofar as the stocking rate of 5 $\mathrm{AU} / \mathrm{ha}$ in the first year and $4 \mathrm{AU}$ in the second year might have not been ideal, generating a low grazing pressure on the pasture, and thus the animals would have greater chances of selecting the feed, which then makes the losses higher and consequently increases the pasture residual height. Therefore, the results for pasture residual height were almost twice as much as the optimal height, which is currently 30 $\mathrm{cm}$ for Tanzania grass, and in periods of lower grazing pressure (year 2) the residual height was around $60 \mathrm{~cm}$.

\section{Evaluation of chemical composition}

Analysis of the chemical composition of the grass revealed a low DM content in year 1 . This may have been because the samples came from the extrusa, because according to some authors (POMPEU et al., 2008; PORTO et al., 2009; FUKUMOTO et al., 2010), addition of saliva to the sample may influence the moisture content of the material. The difference between years, in regard to the DM content, can be explained by the different sampling methods adopted, which, in year 2, was hand-plucking, unlike year 1, whose samples originated from the extrusa.

For mineral matter a significant effect was observed only between years $(\mathrm{P}<0.002)$, with $110.5 \pm 25.4$ and $116.5 \pm 13.3 \mathrm{~g} / \mathrm{kg} \mathrm{DM}$ in years 1 and 2 , were respectively. In this case, it cannot be explained by the salivary contamination, but handplucking in year 2, or simply by a sampling error, given that nothing else would justify the same grass, under the same conditions required by the experiment, showing contrasting differences. However, crude fat content $(24.1 \pm 4.1$ and $5.8 \pm 2.8$ $\mathrm{g} / \mathrm{kg} \mathrm{DM}$ in years 1 and 2 , respectively) can be explained using different sampling methods, i.e., the use of extrusa, in year 1, and hand-plucking in year 2. The changes in inorganic components of esophageal samples can be partially explained by salivary contamination (HOEHNE; CLANTON; STREETER, 1967). Crude fat represents the most energetic fraction of feeds; however, because grasses in general show lower contents as compared with legumes (NRC, 2001), this component is not very relevant, although its evaluation is necessary for the knowledge of its content so as to estimate other fractions, e.g., total carbohydrates.
In cycle 1 of year 1 , Tanzania grass had a greater crude protein content than the other cycles; in year 2 , this increase is only seen with treatment LI95 (Table 3). These differences were expected, because environmental variables associated with the flowering time exert an effect on the grass physiology. Thus, as a rainy season turns into a dry season, the reduction in ambient temperature (Figures $\mathrm{a}$ and $\mathrm{b}$ ) associated with flowering and reduction of nutrient availability (which are conditions normally found under water restriction) may be responsible for the drop in the observed CP content. Paciullo et al. (2001) found that age was the prevailing factor for reducing the nutritive value of leaf blades and stem segments, via increased structural components (NDF) and decreased CP contents. According to Gomide, Gomide and Alexandrino (2007), stem elongation compromises the canopy structure, reducing its leaf/stem ratio, in spite of increased forage accumulation. The CP contents of Tanzania grass observed by Porto et al. (2009) and Fukumoto et al. (2010) are similar to those observed in the present study. Neither the cycle nor the year had a significant effect on fiber content and would therefore not have affected fiber intake. The observed fiber contents can be considered normal for tropical grasses considering their physiological stage at the moment of sampling, and they are similar to those observed by Van Soest (1994), Patês et al. (2008) and Porto et al. (2009), and higher than those observed by Fukumoto et al. (2010).

The lignin content did not vary between the treatments, which demonstrates that the adopted management did not affect the lignification process of the grass. No variation in the lignin content was observed between the grazing cycles in year 1 . Nevertheless, a significant reduction was found in the lignin content in year 2 (Table 4); this decrease can be explained by the water scarcity of the environment observed during the dry spell of year 2 (Figure 2), which resulted in the formation of phenolic compounds such as p-coumaric and ferulic acids, which represent the fraction named lignin (NUSSIO; CAMPOS; LIMA, 2011). Moreover, as its physiological maturation progresses, its lignin and fiber contents increase, i.e., as the grass ages it will have higher lignin and fiber contents, reflecting in reduced digestibility and animal intake.

\section{CONCLUSIONS}

A management strategy employed $95 \%$ light interception promotes the highest percentage of leaves and smaller percentage of stems, thus 
ensuring a greater pre-grazing leaf/stem ratio. Therefore, promoted an increase in the protein content of grasses.

A greater number of grazing cycles performed during the rainy season and shorter grazing intervals (approximately 24 days) are possible when adopting a rest period based on $95 \%$ light interception compared to a fixed rest period of 30 days.

RESUMO: O objetivo deste trabalho foi avaliar as características morfogênicas e a composição química do capim-tanzânia, utilizando um período de descanso fixo ou de acordo com a interceptação luminosa a 95\%. Os tratamentos consistiram de avaliações de duas estratégias de manejo de pastagem de capim Tanzânia: (1) LI95 - animais entraram nos piquetes quando o pasto atingiu 95\% de interceptação luminosa (LI), com três dias de ocupação do piquete; e (2) FR - a pastagem foi manejada com um intervalo de desfolhamento (DI) de 30 dias e três dias de ocupação do piquete. A área experimental consistiu de 4 ha, com 22 piquetes por tratamento. Dez vacas recém-paridas foram utilizadas por tratamento no ano 1, e oito vacas foram utilizadas por tratamento no ano 2. A altura do pasto, a massa de forragem e os componentes morfológicos e sua composição química foram avaliados. As estratégias de manejo utilizadas na pastagem de capim-Tanzânia não afetaram a massa ou a altura do pasto nas condições pré e pós-pastejo, ou a proporção de hastes. No entanto, a proporção de folhas foi maior nos piquetes com 95\% de interceptação de luz. O teor de proteína bruta foi maior nos piquetes com 95\% de interceptação de luz; os outros nutrientes não foram afetados. Em conclusão, o manejo adotando $95 \%$ de interceptação de luz não influencia as características morfogenéticas. No entanto, promove um aumento no teor de proteína bruta das gramíneas.

PALAVRAS CHAVES: Intensidade de desfolha. Interceptação luminosa. Piquetes. Taxa de lotação. Vacas mestiças.

\section{REFERENCES}

AKAIKE, H. A new look at the statistical model identification. IEEE Transactions on Automatic Control, v. 19, p.716-723, 1974. https://doi.org/10.1109/TAC.1974.1100705

ALEXANDRINO, E.; GOMIDE, J. A.; GOMIDE, C. A. M. Crescimento e Desenvolvimento do Dossel de Panicum maximum cv. Mombaça. Revista Brasileira de Zootecnia, v. 34, p.2164-2173, 2005. https://doi.org/10.1590/S1516-35982005000700002

AOAC - Association of Official Analytical Chemistry. Official methods of analysis. 15th ed. AOAC International. Arlington: 1990. 1298 p.

BURNHAM, K. P.; ANDERSON, D. R. Multimodel inference: understanding Aic and Bic in model selection. Sociological Methods and Research, v. 33, p.261-304, 2004. https://doi.org/10.1177/0049124104268644

FUKUMOTO, N. M.; DAMASCENO, J. C.; DERESZ, F., MARTINS; C. E.; CÓSER, A. C.; SANTOS, G. T. Produção e composição do leite, consumo de matéria seca e taxa de lotação em pastagens de gramíneas tropicais manejadas sob lotação rotacionada. Revista Brasileira de Zootecnia, v. 39, p.1548-1557, 2010.

GOMIDE, C. A. M.; GOMIDE, J. A.; ALEXANDRINO E. Índices morfogênicos e de crescimento durante o estabelecimento e a rebrotação do capim-Mombaça (Panicum maximum Jacques). Pesquisa Agropecuária Brasileira, v. 42, p.1487-1494, 2007. https://doi.org/10.1590/S0100-204X2007001000017

HOEHNE, O. E.; CLANTON, D. C.; STREETER, C. L. Chemical Changes in Esophageal Fistula Samples Caused by Salivary Contamination and Sample Preparation. Journal of Animal Science, v. 26, p.628-631, 1967. https://doi.org/10.2527/jas1967.263628x 
LEE-STADELMANN, O. Y.; STADELMANN, E. J. Cell permeability and water stress. In: LANGE, O.L.; KAPPEN, L.; SCHULZE, E.D. (Eds). Water and Plant Life: Problems and Modem Approaches. Berlin: Spinger-Verlag. 1976. p. 268-280. https://doi.org/10.1007/978-3-642-66429-8_17

LEMAIRE, G.; CHAPMAN, D. Tissue fluxes in grazing plants communities. In: HODGSON, J.; ILLIUS, A. (Eds). The ecology and management of grazing systems. Wallingford: CAB International. 1996. p. 3-36p.

LITTELL, R. C.; MILLIKEN, G. A.; STROUP, W. W.; WOLFINGER, R. D.; SCHABENBERGER, O. (2006). SAS ${ }^{\circledR}$ for Mixed Models, North Caroline: SAS Institute Inc., Cary. 2006. 814p.

NRC - National Research Council. Nutrient requirements of dairy cattle. 7. ed. Washington: National, Academy Press. 2001. 405p.

NUSSIO, L. G.; CAMPOS, F. P.; LIMA, M. L. M. (2011). Metabolismo de carboidratos estruturais. In: BERCHIELLI, T.T.; PIRES, A.V.; OLIVEIRA, S.G. Nutrição de Ruminantes. Jaboticabal: FUNEP. 2011. p. 193-234.

PACIULLO, D. S. C.; GOMIDE, J. A.; QUEIROZ, D. S.; SILVA, E. A. M. Composição química e digestibilidade in vitro de lâminas foliares e colmos de gramíneas forrageiras, em função do nível de inserção no perfilho, da idade e da estação de crescimento. Revista Brasileira de Zootecnia, v. 30, p.964-974, 2001. https://doi.org/10.1590/S1516-35982001000400009

PATÊS, N. M. S.; PIRES, A. J. V.; CARVALHO, G. G. P.; OLIVEIRA, A. C.; FONSÊCA, M. P.; VELOSO, C. M. Produção e valor nutritivo do capim-tanzânia fertilizado com nitrogênio e fósforo. Revista Brasileira de Zootecnia, v.37, p.1934-1939, 2008. https://doi.org/10.1590/S1516-35982008001100005

POMPEU, R. C. F. F.; CÂNDIDO, M. J. D.; NEIVA, J. N. M.; ROGÉRIO, M. C. P.; FACÓ, O. Componentes da biomassa pré-pastejo e pós-pastejo de capim-tanzânia sob lotação rotativa com quatro níveis de suplementação concentrada. Revista Brasileira de Zootecnia, v. 37, p.383-393, 2008.

https://doi.org/10.1590/S1516-35982008000300002

PORTO, P. P.; DERESZ, F.; SANTOS, G. T.; LOPES, F. C. F.; CECATO, U.; CÓSER, A. C. Produção e composição química do leite, consumo e digestibilidade de forragens tropicais manejadas em sistema de lotação intermitente. Revista Brasileira de Zootecnia, v. 38, p.1422-1431, 2009. https://doi.org/10.1590/S1516-35982009000800005

RAY, J. D.; SINCLAIR, T. R. The effect of post size on growth and transpiration of maize and soybean during water deficit stress. Journal of Experimental Botany, v. 49, p.1381-1386, 1998. https://doi.org/10.1093/jxb/49.325.1381

SANTOS, M. E. R.; FONSECA, D. M.; GOMES, V. M.; PIMENTEL, R. M.; ALBINO, R. L.; SILVA, S. P. Signal grass structure at different sites of the same pasture under three grazing intensities. Acta Scientiarum. Animal Sciences, v. 35, p. 73-78, 2013. https://doi.org/10.4025/actascianimsci.v35i1.11801

SNIFFEN, C. J.; O'CONNOR, J. D; Van SOEST, P. J.; FOX, D. G.; RUSSELL, J. B. A Net Carbohydrate and Protein System for Evaluating Cattle Diets. II. Carbohydrate and Protein Availability. Journal of Animal Science, v. 70, p. 3562-3577, 1992. https://doi.org/10.2527/1992.70113562x

UEBELE, M. C. Padrões demográficos de perfilhamento e produção de forragem em pastos de capimmombaça submetidos a regime de lotação intermitente. 2002. 79p. Dissertação (Mestrado em Agronomia) Universidade de São Paulo. 2002.

VAN SOEST, P. J.; ROBERTSON, J. B.; LEWIS, B. A. Methods for dietary fiber, neutral detergent fiber, and nonstarch polysaccharides in relation to animal nutrition. Journal of Dairy Science, v.74, n. 10, p.3583-3597, 1991. https://doi.org/10.3168/jds.S0022-0302(91)78551-2 
VAN SOEST, P. J. Nutritional ecology of the ruminant. 2. Ed. Ithaca, NY: Cornell University. 1994. 488p. https://doi.org/10.7591/9781501732355

WANG, J. P.; BUGHRARA, S. S; NELSON, C. J. Morpho-physiological Responses of Several Fescue Grasses to Drought Stress. Hort Science, v.43, p.776-783, 2008. https://doi.org/10.21273/HORTSCI.43.3.776

ZANINE, A. M.; NASCIMENTO JUNIOR, D.; SILVA, W. L.; SOUSA, B. M. L.; FERREIRA; D. J.;

SILVEIRA, M. C. T.; PARENTE, H. N.; SANTOS, M. E. R. Morphogenetic and structural characteristics of guinea grass pastures under rotational stocking strategies. Experimental Agriculture, v. 54, p.:243-256, 2016. https://doi.org/10.1017/S0014479716000223 